\title{
EMU: AN EVALUATION OF THE ASYMMETRIC SHOCK PROBLEM
}

\section{Özgün İMRE*}

\begin{abstract}
Economic and Monetary Union (EMU) has a unique set up: while the monetary policy is centralised at the Union-level, the fiscal policies are left to the member states within the limitations of the Stability and Growth Pact. The Commission argues that within time EMU would constitute an optimum currency area, and further centralisation of fiscal policies, thus, is not needed. Fiscal federalism literature, on the other hand argues that stabilisation functions should be centralised, since no individual would be able to deal with an asymmetric shock without harming another member. Therefore the fiscal policy centralisation should accompany the monetary centralisation.

This study tries to assess whether the EMU has become more symmetric over time. By proposing a centralised insurance against asymmetric shock, and linking the trend of the stabilisation provided by the insurance scheme to the ability of EMU to absorb asymmetric shocks, the results of the study suggests that EMU has become more symmetric over time.
\end{abstract}

Keywords: EMU, OCA, Asymmetric Shock, Fiscal Federalism, Jel Codes: C23, E63, $H 77$

\section{AVRUPA PARA BİRLİĞì: ASIMETRIKK ŞOK PROBLEMİ ÜZERİNE BİR DEĞERLENDİRME}

\section{Özet}

Avrupa Para Birliği (APB) kendine has bir şekilde kurulmuştur: para politikalart merkezileştirilirken mali politikalar Istikrar ve Büyüme Paktı sinırlart içerisinde üye devletlerin yönetiminde bırakılmıştır. Komisyon, APB'nin zaman içinde bir optimum para sahası haline geleceğini, bu yüzden de mali politikaların merkezileştirilmesinin gerekmeyeceğini öne sürmüşü̈r. Mali federalizm literatürü ise bir birlikte, üyelerin diğerlerini olumsuz yönden etkilemeden asimetrik şokları

\footnotetext{
* International and European Relations, Linköping University, e-mail: ozgunimre@ gmail.com
} 
asimile edemeyeceğini, bu yüzden istikrar sağlama politikalarının merkezileştirilmesini önermektedir. Bu yüzden para politikasının merkezileştirilmesi mali politikaların da merkezileştirilmesiyle pekiştirilmelidir.

$B u$ çalışma APB'nin zaman içinde daha simetrik bir yapıya kavuşup kavuşmadı̆̆ını araştırmaktadır. Önerilen bir merkezi sigorta mekanizmasıyla, zaman içinde değişen modelin istikrar sağlama yetisi ve APB'nin asimetrik şoklarla baş edebilme becerisi bağdaştırılmış ve APB'nin zaman içinde daha simetrik bir yapı haline geldiği görülmüsstür.

Anahtar Kelimeler: Avrupa Para Birliği, Optimum Para Sahası, Asimetrik Şoklar, Mali Federalizm

\section{Introduction}

During the global financial crisis, the ability of the European Monetary Union (EMU) to survive the turbulent times was discussed heavily. With the various bailout schemes, it seems that Eurozone has managed to overcome the most serious obstacle it has faced as of yet. However, the crisis was successful in making us question the rationality of the set-up of the system. Fraudulent behaviour of Greece in entry to $\mathrm{EMU}^{1}$ (Eurostat, 2004; BBC, 2004) and the cover up of budget deficit in the financial crisis (Faiola, 2010), the coming calls for bail-out from Greece and Ireland during the crisis, and the bail-out plans for Portugal in 2011 shows the weakness of the system, and how countries were left open to the effects of an asymmetric shock.

In a case where the asymmetries exist, one possible way to offset the asymmetric effects of crisis in a monetary union is to have a centralised insurance scheme. However the member states argue against such a centralised scheme, just as the European Commission (hereafter Commission) is arguing that EMU would constitute an optimum currency area (OCA) with time, which would result in lessened asymmetries in the Union.

This paper aims to evaluate the ability of EMU to offset asymmetric shocks, answering the question "To what extent could a centralised insurance scheme provide stabilisation for asymmetric shocks in EMU?" By calculating the change in the potential coverage provided by a centralised insurance scheme over the years, this study will investigate the evolution of the asymmetric shock problem in EMU, arguing that a decrease in the coverage would point to a more symmetric EMU that

\footnotetext{
${ }^{1}$ Eurostat (2004) argues that, though the revisions of past years are not unusual, the revision of Greek government finances were extreme, and the misreporting of the statistics by not following the ESA-95 rules - which resulted in lower debt and deficit figures - were detrimental to the system.
} 
would face less asymmetric shocks, rendering a centralised insurance scheme pointless in time.

This introduction is followed by the second part evaluating EMU by OCA criteria. The third part discusses the arguments for and against a centralised insurance scheme, with the fourth part evaluating the insurance coverage provided by a hypothetical insurance scheme. The results are discussed in the conclusion.

\section{Asymmetric Shocks and EMU}

Asymmetric shocks, in the simplest sense, can be defined as shocks that affect the countries differently. In a group of countries attempting to establish a monetary union, it is important that the risk of asymmetric shocks is minimal, as the member countries would be unable to offset the shocks by using the monetary policies.

Mundell (1961) argues that since the members would tie their monetary policy, they would have to rely on inter-regional factor mobility to overcome an asymmetric shock. By following Mundell (1961) one can depict this adjustment in a two stage game: In the first stage the two regions, $\mathrm{A}$ and $\mathrm{B}$, are facing an asymmetric demand shock, with region A being positively affected. With increased demand, the price of the product increases in A, pushing the wages up, and therefore lowering the propensity of employers to employ new labour, whereas in region B the low demand causes firms to lay off the labour. If as Mundell (1961) argues for, there exists inter-regional factor mobility, in the second stage of the game, the surplus labour of B would move to A, thus lowering the wages, and enabling the employers to increase the supply of product by employing new cheap labour. In the case when the adjustment cannot be achieved, the expected result in the second stage would be rising inflation and unemployment rates in the region $\mathrm{A}$ and $\mathrm{B}$, respectively.

The real world is unlikely to have perfect factor mobility, and therefore it is highly probable that EMU would face asymmetric shocks. As Wildasin (2000) argues, the adjustments to the asymmetric shocks would be lagged due to intrinsic factors like language barriers, transportation costs, etc., as well as policy barriers that limit factor movement.

De Grauwe (2005) argues that a symmetric shock can also act like an asymmetric shock. If the member states have different preferences for employment and inflation, a symmetric shock would be felt differently. Arguing that inflation would be more closely controlled by the union, it is therefore expected that the asymmetric effects would emerge in the unemployment figures of a hypothetical two player setting. De Grauwe and Senegas (2003) argues that in such cases where the symmetric shock can act as an asymmetric shock, the central bank should pay attention to national information on inflation and output gaps, which would be 
incompatible with ECB's “one size fits all” stance. The global financial crisis provided an example for this kind of shock, while some members were affected more severely; the others had relatively easier time of adjustment to the crisis.

One way to assess the ability of a monetary union to overcome an asymmetric shock, as well as its propensity to face asymmetric shocks, is to use the tools provided by the OCA theory. OCA can be defined as "the optimal geographic domain of a single currency, or of several currencies, whose exchange rates are irrevocably pegged and might be unified" (Mongelli, 2002: 7). By forming a monetary union, the members expect to gain by lowered transaction costs, increased trade flows, etc., which would out-weight the cost of centralised monetary policy in an OCA. And to constitute an OCA, the members should have flexible labour markets and/or high economic integration (De Grauwe, 2005) among themselves before they establish a monetary union.

The classic principles of OCA theory ${ }^{2}$ were later criticised for being static, and having no room for a change after the establishment of the union. Frankel and Rose (1997) argued that the union would resemble an OCA after its formation, even if it didn't constitute an OCA beforehand, similar to the opinion expressed in "One Market One Money" (Commission, 1990) which argued that EMU would face less asymmetry with increasing integration as a result of monetary union. Commission's opinion was opposed by Krugman (1993) who argued that the asymmetries would further deepen after EMU. ${ }^{3}$

Following the first principle laid down by Mundell (1961), figure 1 shows the labour market rigidity of the Euro Area (EA). With more rigidity in the labour markets, ceteris paribus, it is expected that the member states would be affected more easily by an asymmetric shock and that the adjustment would take longer than the case with flexible labour markets. With higher values representing higher rigidity, it can be seen from the figure that the EA has a more rigid labour market than the US and the UK

\footnotetext{
${ }^{2}$ These classic principles can be summarised as : inter-regional factor mobility (Mundell, 1961), open economies (McKinnon, 1963), diversified economies (Kenen, 1969). On a survey of OCA theory see: Mongelli (2002).

${ }^{3}$ There is no consensus in the literature on the level of shock convergence, as well as its importance to assess the costs of joining to a monetary union, in EMU. While some of the literature argues that there is an ex-post convergence for demand shocks, another strand finds no evidence of convergence of supply shocks, while a third branch suggests the convergence is a general trend, not linked to EMU. For a survey, see Babetskii (2004).
} 
Figure 1. Indices of Labour Market Rigidity

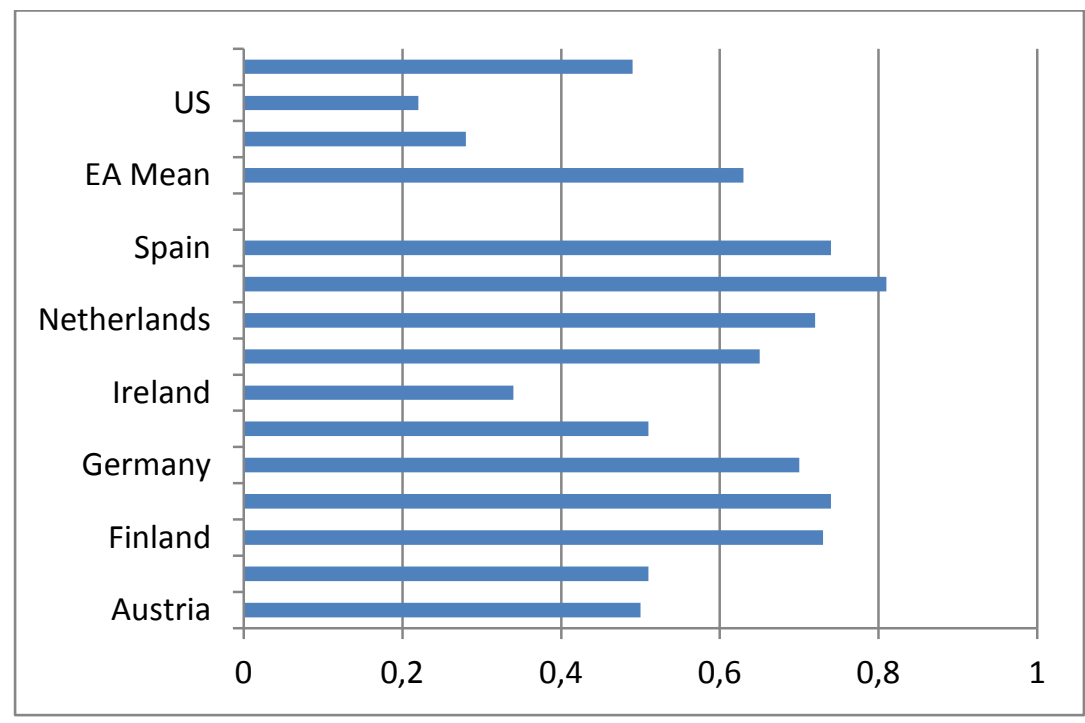

EA: Austria, Belgium, Finland, France, Germany, Greece, Ireland, Italy, the Netherlands, Portugal and Spain. Luxembourg is missing from the original dataset, therefore is not included in the EA-mean.

Source: Botero et al. (2004)

Siedschlag (2008) argues that labour mobility in EMU is still problematic, and that even if it can be argued that the members may have converged in other areas, this low mobility would make the adjustments harder. The UK's economics and finance ministry, HM Treasury (2003), while comparing wage bargaining centralisation, claims that the continental countries have more rigid labour markets than the UK, a similar conclusion to Botero et al. (2004), with Clar et al (2007) arguing that regulated markets with higher union density would result in sluggish adjustment to shocks.

As mentioned previously, Frankel and Rose (1997) argue that EMU would resemble an OCA after it is established. They argue that EMU would result in increased trade, which in turn would cause a convergence of the business cycles of the member states, thus lowering a chance of asymmetric shock. Berger and Nitsch (2008) argue that the Euro didn't play a significant role in the increase of trade among EMU members, and that the increase observed was a trend that started before EMU. Berger and Nitsch (2010) further claim that the labour market rigidities of EMU members are one of the reasons for the persistent trade imbalances. Schiavo (2008) on the other hand argues that the observed capital market integration suggests the existence of convergence of business cycles, 
whereas Cuaresma and Amador (2007) suggest that, although it is possible to talk of a convergence of business cycles, that convergence pattern stops at year 2003 and turns into a divergence pattern after that.

In financial market integration, Buti and van den Noord (2009) find that EMU resulted in a drop in home bias ${ }^{4}$. Demyanyk et al. (2008) argue that the greater integration resulted in increased risk sharing, but they also state that the risk sharing is too low when compared to the risk sharing found in the US. Furthermore they claim that the income smoothing effect of the increased integration arises mostly from the investment done outside of EMU. However, overall the financial market integration seems more successful than the trade integration in EMU.

Uncorrelated shocks also provide an assessment of the likelihood of an asymmetry in the system. Broz (2008) finds that the correlation of shocks of the 1995-2006-period is higher than in the 1995-98 period, even though it is lower than the 1999-2002 period, and argues that, although one can speak of a general convergence, the existence of the differences in the member states should be kept in mind. GDP growth correlation, when taken as an indicator of a possible asymmetric shock problem, shows that some members of EMU would be better off without EMU, while some new members of EU are more symmetric to the EMU average than the existing EMU members. (Demyanyk and Volosovych, 2005; Broz, 2008)

So far it seems unclear if the EMU can be termed as an OCA. While there are some improvements in financial market integration, as argued by Frankel and Rose (1997), there is also evidence pertaining to an earlier trend of integration, thus making the effect of EMU on the integration debatable. It was shown during the global financial crisis that the achieved integration was not able to alleviate the effects of the crisis.

The global financial crisis when taken as an exogenous variable, can - as discussed before - act as an asymmetric shock. Edwards (2008: 5-8) argues that the openness of the member states - which was mentioned to increase by EMU - could cause unwanted consequences if not supplemented by needed reforms, which according to Commission (2009a) were lacking. Before arguing about the asymmetric effects of the crisis however, the asymmetry in treating the crisis by the political elites should be mentioned. The early days of the crisis saw an uncoordinated crisis management: Ireland's unilateral savings guarantee, its criticism by Germans, Germany's all savings guarantee that followed Ireland in a

\footnotetext{
${ }^{4}$ Lane (2008: 16) argues that though there is an overall increase in foreign asset holding in EMU, some countries has a preference towards some specific markets, i.e. Spain and Portugal's bias towards Latin American markets.
} 
few days, UK's use of anti-terrorist laws to seize deposits of some of the banks, etc. (Lian, 2008; Hall, 2008; Braithwaite et al., 2008)

With the introduction of the European Economic Recovery Programme, the efforts to manage the crisis became more coordinated. However, due to the already divergent economies, some member states, i.e. Italy and Greece, couldn't adopt fiscal stimulus packages (Commission, 2009b). Budget deficit and public debt of all EMU members have worsened during the crisis, however the worsening was not a uniform process: the countries that already had unstable economies became more unstable - thus unable to use adjustment mechanisms - while some member states were able sustain a budget surplus and stay within the Maastricht limits. Ferreiro et al. (2009) also argue that even if one can talk about a convergence toward the Maastricht limits prior to the crisis, the quality of the public expenditures is asymmetric among the member states.

FDI inflow/outflows of EMU members were also influenced differently by the crisis. While the FDI inflows fell approximately by 55\% for EMU, Netherlands saw a $100 \%$ decrease in inflows whereas Finland experienced a 100\% increase (OECD, 2009). Christodoulakis (2009: 25-26) argued that the asymmetry was also evident in the investment patterns, with southern members attracting investment in nontradable goods.

As can be seen, EMU members have considerable risk of facing asymmetric shocks, and therefore need an adjustment mechanism. One adjustment mechanism is the centralisation of the fiscal policies, and creating an insurance scheme. Before investigating what a central insurance scheme can offer to EMU, the next part discusses such federal schemes to lay the groundwork for the analysis.

\section{Federal Insurance Schemes}

The idea of a centralised, or as some may call, federal insurance schemes is closely interlinked with fiscal federalism. Fiscal federalism, as Oates (1999: 1120) puts tries "... to understand which functions and instruments are best centralized and which are best placed in the sphere of decentralized levels of government". Thus one can argue that the fiscal federalism literature investigates the problem of assigning the public goods provision to different levels of government.

In his seminal work, Oates (1972: 35) put forward the decentralisation theorem, which argued that under a number of assumptions, the public good provision should be handled with the lowest level of government possible, as long as it is as costly as it is in the case when the provision is done from a higher level of government. This suggestion is in line with the subsidiarity principle of EU, which argues that EU can act only if the action needed cannot be attained by the member states. However, as 
later argued by Oates (2006), the assumptions of the theorem, be it implicit or explicit, are not in line with the real world.

The goods that are provided are assumed to be consumed at a defined geographical space; therefore the citizens will not move to a different jurisdiction as a result of a fiscal change in their jurisdiction. This near perfect immobility, as discussed before is unrealistic, and also unwanted, since it will limit the adjustment available to the jurisdictions. The central government is assumed to provide uniform goods to the whole population. However some studies show that the central government provides differentiated goods to certain jurisdictions. Lockwood (2002) argues, for example, that if there is a minimum winning coalition, it is highly probable that the central government will provide more benefits to the jurisdictions in the coalition. A third assumption relates to the lack of spill overs. With the effects of goods consumed bound by geographical borders, the negative and positive spill-overs are discarded.

Since it is possible to find an evidence supporting both the centralisation and decentralisation of the provision of public goods, it is necessary to see what the advantages/disadvantages provided by them are. As Oates (2006) argues, decentralisation provides benefits by putting the public good provision to the levels where information asymmetries are low; by increasing inter-jurisdictional competition; by providing the jurisdictions the ability to experiment; and by creating the groundwork for Weingast's (1995) market preserving federalism ${ }^{5}$.

On the other hand as Rosen (2005: 512-15) argues, decentralization carries some disadvantages. By decentralizing, the government loses the ability to internalize the spill-overs, loses the economies of scale, and therefore some of its potential finance. The different structures of tax systems also provide a disincentive for decentralization, since they may create a race-to-the-bottom. Also some kind of income transfers from the richer regions to the poor seems inevitable in all countries; therefore a decentralized system that will limit such transfers would be opposed by some groups of the citizens.

It was discussed earlier that the decentralization theorem omitted the spill-overs: Rosen (2005: 515) argues that decentralization can lead to spill-overs and suggests that for the internalization of such spill-overs the policy area should be left to the central governments. If the spill-over just affects a certain region, the centralization

\footnotetext{
${ }^{5}$ For such a federalism to exist there must be some conditions met: (i) there must be a hierarchy of government with delineated scope of authority, (ii) there must be a common market with factor and labour mobility, (iii) local governments should have both local regulation of the economy and authority over public goods and service provision for the local economy, (iv) the authority should be institutionalized, and (v) local governments should have hard budget constraints (Weingast, 2007: 6).
} 
of the policy to a regional level would be a solution ${ }^{6}$, and if the spill-over is nationwide the policy should be centralized to the national level.

After looking at the decentralization theorem, and the advantages and disadvantages of decentralization, one can come up with a possible way to assign the provision of public goods to various levels of government. Following Oates (1968), and using Musgrave's (1959, cited in Musgrave, 2008) division of public goods it can be argued that the stabilization components, namely the monetary and fiscal policy, should be centralized, since the individual members would be unable to internalize the spill-overs, and unable to enjoy the benefits of economies of scale. The distribution components, especially if the factor mobility is low, would better be suited to the centralized level. The allocation components however would necessitate a more case-by-case analysis. Though it can be argued that regulation should be left to the central government, it is not always economically efficient to do so; while the state-as-a-producer may work well with pure public goods, impure public goods may be better left to the local jurisdictions.

After arguing that EMU doesn't necessarily constitute an OCA, and giving a plausible rationale for having the fiscal policy centralized by the fiscal federalism literature, fiscal policy integration can be investigated in further detail. Kenen (1969) had already called attention to the need of fiscal policy integration well before EMU was founded. And today, even though it is accepted that fiscal policy may not play the role that it did in Keynesian economics, the automatic stabilization effect of the fiscal policies can be an answer to the asymmetric shocks.

In a case where the fiscal policies of the members are integrated, at least to some extent, the adjustment to an asymmetric shock can be attained by fiscal transfers, i.e. social security transfers. The positively affected member would have increased social contributions, due to increased demand for labour, whereas in the negatively affected country, the social contributions would drop due to lay-outs while the demand for unemployment insurance and compensations will increase, depleting the funds. In a monetary union with integrated fiscal policies, the union budget would transfer the excess contributions from the positively affected to the negatively affected, therefore softening the possible effects of the shock.

Catenaro (2000) argues for strong coordination of fiscal policies in a monetary union, since without coordination the effects of fiscal policy in one country can have opposite reactions in another member: He argues that with employment linked to inflationary surprises, spending surprises and expected tax distortions, the member states should have coordinated fiscal policies. Similar to this, Bayoumi and

\footnotetext{
${ }^{6}$ In contemporary U.S., the local jurisdictions are prone to centralise some policy areas, and as Weingast (2007: 31) argues these special governments are the largest category in local jurisdictions, and they are growing fastest.
} 
Masson (1998) argue that a federal system would perform better than a national system, and that this doesn't necessarily mean the abolishment of the national policies.

It also can be argued that individuals can insure themselves against the shocks by participating in the financial markets, therefore diversify their risk to various assets. Leaving the issues associated with financial market integration and homebias aside, which are not necessarily solved, Crossley and Low (2004: 45) argue that $25 \%$ of job losers do not have access to credit markets, therefore leaving a significant portion of the effected population without insurance. The national government can also provide insurance for the citizens. However, as the global financial crisis showed, the countries with bad fiscal stances couldn't provide fiscal stimulus packs and had to face higher interests rates for borrowing from the international markets. The insurance by the state then would not be sustainable if the crisis lasted longer than anticipated. Von Hagen (1998: 7) summarizes the superiority of a federal insurance to the national insurance as:

"Self-insurance implies that increased government spending during a recession is matched by a future tax liability. Rational, forwardlooking consumers anticipate the future tax payments and reduce consumption accordingly. Under intra-national insurance, in contrast, transfers paid to a depressed region do not increase that region's expected future tax liabilities, if the expected value of future asymmetric shocks is zero and the insurance scheme is balanced across regions."

Favouring a centralized solution, Evers (2006) argues that a federal transfer scheme, consisting of household and intergovernmental transfers, provides perfect insurance against asymmetric preference and productivity shocks. De Grauwe (2006) argues for a central budget, capable of redistribution for the Union, to reduce the effect of asymmetric shocks ${ }^{7}$.

The Commission (1990) on the other hand argues that the budget of the EU (EMU) would remain unchanged for the foreseeable future, therefore unable to undertake a centralized insurance scheme, and argue that the Stability and Growth Pact would be enough to oversee the members' fiscal positions. (Commission, 2006; Bini Smaghi, 2007) Buti and van den Noord (2004: 9) suggest that the subsidiarity principle should be taken into account and that the differences of members should be incorporated to the formulation of the fiscal rules for the union.

\footnotetext{
${ }^{7}$ Some of the adjustment mechanisms to the global financial crisis were akin to a limited centralisation of the fiscal policies, in line with the fiscal federalism literature. For some of the examples, see: Gros and Mayer(2010), De Grauwe and Moesen (2009), Delpla and von Weizsäcker (2010).
} 
Jones (2009) argues that both the richer and poorer members of EMU would prefer a status-quo for the foreseeable future, both shying away from contributing to the system and creating more cost to their national economies.

Both the Werner Report (1970) and the Delors Report (1989) argued in favour of a centralized fiscal scheme, and McNamara (2005: 155) points out that the currency unions that didn't turn into fiscal unions have failed to exist. Against these opinions and the general tendency of the fiscal federalism literature to recommend a centralized fiscal policy for monetary unions, the next part sketches out a central fiscal scheme for EMU.

\section{EMU-wide Insurance Scheme}

There have been various proposals for an EMU wide insurance scheme in the history. Sala-i Martin and Sachs (1991) argue that the EU lacks the fiscal transfer schemes found in the US, and that it needs extra features to offset this situation, which is mirrored in Bayoumi and Masson (1995). Von Hagen (1992) argues that Sala-i Martin and Sachs (1991) have over-estimated the importance of fiscal transfers in the US, while Fatas (1998) argues that the figures for Europe are too low, and that the national states provide $50 \%$ of shock coverage.

Bayoumi and Masson (1998) find that in Canada, the fiscal transfers can provide $14 \%$ shock coverage, and urge Europe to look into establishing similar systems. Italianer and Vanheukelen (hereafter I and V) (1993) argue that a hypothetical insurance scheme for EMU can provide 19\% shock coverage, while Bajo-Rubio and Diaz Rolden (2000) find a shock coverage around 10\% for the affected countries. Dullien and Schwarzer (2005) argue that with a transfer scheme based on corporate tax and an unemployment scheme, $15-20 \%$ of regional downturns in EMU can be offset. Hammond and von Hagen (1998) argue that only with complex econometric formulas can the EMU provide a significant insurance against asymmetric shocks.

For the purposes of this paper, the model proposed by I and V (1993) would be used. This model is chosen due to its simplicity and low moral hazard. Since the main purpose of the study is to assess how the EMU's ability to offset asymmetric shocks has changed over time, the financing and how the insurance would be used by the member states would not be discussed ${ }^{8}$. If there is a downward trend of the insurance coverage estimations, this would imply that - for whatever the reason the asymmetries that the EMU faces are decreasing, thereby reducing the insurance a centralized scheme can provide.

\footnotetext{
${ }^{8}$ These issues were also mostly side-stepped by I and V (1993). Several financing schemes were offered by others, i.e. earmarked tax revenues, use of special bonds etc. See Bajo-Rubio and Diaz-Rolden (2000) for a model that uses a predetermined percentage of VAT revenues.
} 
The unemployment figures of the member states can provide a crude estimation of the asymmetric shocks. Unemployment indicators are relatively harmonised and become available with a short lag, therefore enabling the use of unemployment rates to estimate an economic shock faced by the member states. Following I and V (1993), the use the insurance funds are conditional to:

$$
\begin{aligned}
& d U_{i}(t)>0, \\
& d U_{i}(t)>d U_{E M U}(t)
\end{aligned}
$$

The change in unemployment rate in country $i$, in month $t, d U_{i}(t)$ is calculated by subtracting the unemployment rate of month $(t-12), U_{i}(t-12)$, of country from unemployment in month $t, U_{i}(t)$, formulated as:

$$
\begin{aligned}
& d U_{i}(t)=U_{i}(t)-U_{i}(t-12) \\
& d U_{E M U}(t)=U_{E M U}(t)-U_{E M U}(t-12)
\end{aligned}
$$

A difference version of Okun's law ${ }^{9}$ is used to estimate the asymmetric shock:

$$
d U_{i}(h)=\gamma-\sigma g_{i}(h),
$$

With $d U_{i}(h)$ being the annual change of unemployment rate and $g(h)$ being the annual growth rate of GDP of country $i$ in year $h$. By using Euro Area-12 (EA-12) data for the period of $1984-2007^{10}$, the Okun's law estimations (with standard errors in parenthesis) $\operatorname{are}^{11}$ :

$$
\begin{gathered}
d U_{i}(h)=0.793-0.229 \\
(0.11) \quad(0.02)
\end{gathered}
$$

This can be interpreted as the average trend growth of the Union was $3.4 \%$ $(0.79 / 0.22)$, meaning that to sustain such employment figures in the EA-12, the Union has to grow at least $3.4 \%$ every year. In the case of lower growth, it is expected that the Union would face increasing unemployment. For every $1 \%$ of deviation from the trend growth would result in a of $0.22 \%$ increase in the unemployment. Okun's law then would suggest that shocks and real economic activity are inversely linked.

\footnotetext{
${ }^{9}$ Okun's Law estimates the relationship between unemployment and GDP, and argues that a deviation from the trend growth would result in a change in the unemployment in the country. For a survey on Okun's law, see: Knotek (2007)

${ }^{10}$ The omission of the post 2007 data is intentional. The global financial crisis was of a severity that necessitated extra adjustment mechanisms to offset the shocks. For an estimate on how the financial crisis affected the shock coverage by a hypothetical insurance system, see Imre (2010).

${ }^{11}$ The equation also contains a significant negative trend.
} 
Following I and V (1993: 496), if one assumes that each percentage point difference, with respect to the change in the average of the partners, implies a payment equal to a given percentage, $\alpha$, of last year's GDP, with $\alpha=1$, the stabilization provided by the system would be $22 \%$ of the shock ${ }^{12}$. In other words, for a shock that had the effect equivalent to a $1 \%$ of the GDP, the effected country would benefit from the fund amounting to $0.22 \%$ of its GDP, therefore stabilising $22 \%$ of the shock.

As previously stated, this paper aims to assess if the EMU (for the estimations provided, EA-12) has improved in terms of lowering its risk to asymmetric shocks. In the case where EMU had succeeded in doing so, for whatever the reason may be, the insurance provided by the scheme would fall. To assess this, the paper compares the results of estimations for Okun's law for various periods, starting from the 1984-1994 period until the whole 1984-2007 period is covered. As seen in the figure 2 , the stabilisation provided by the scheme (the absolute value of $\sigma$ ) has decreased over time.

Figure 2. Shock Coverage Over Time

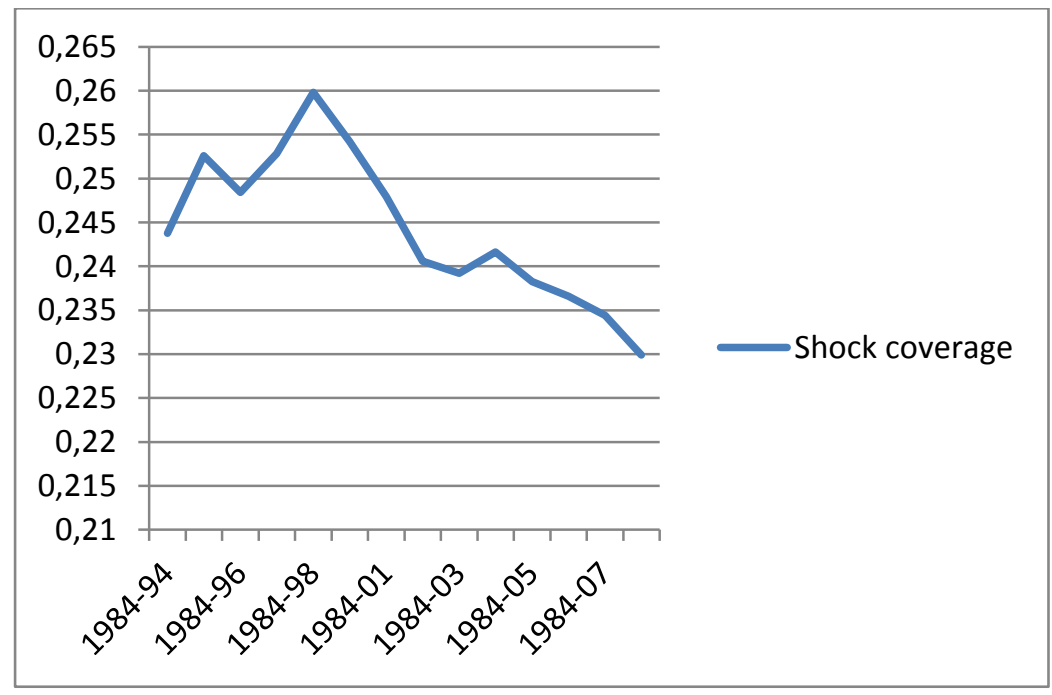

Source: Author's estimations

Even though the decrease of the stabilisation hasn't been perfectly steady over the investigated period, the general tendency has been a decrease in the potential

\footnotetext{
${ }^{12}$ This estimation of the model relies on the assumption that only one state is affected by the shock. If the shock is more severe, or affects more countries the stabilisation provided would change accordingly.
} 
shock coverage values over time. ${ }^{13}$ It is of interest to note that the establishment of the EMU also coincides with a break of the increasing shock coverage trend that was observed in the 1990s. However, this does not necessarily mean that the EMU had a significant effect on the shock coverage; as some have argued, this can be a result of many variables that are irrelevant to the EMU project.

\section{Conclusion}

This paper tried to investigate the risk of asymmetric shocks that the EMU faces. By arguing that a centralised shock coverage scheme could be of use against asymmetric shocks, as was proposed by the fiscal federalism literature, the ability of EMU to overcome these shocks was assessed.

The findings of the model suggest that the stabilisation provided by a hypothetical centralised insurance scheme has declined over time. The post-EMU period has a trend of decreasing stabilisation offered by the scheme, therefore suggesting that the EMU is becoming more symmetric. This is contradictory to the pre-EMU period investigated, which has shown a trend of increasing shock coverage, in the 1990s until the establishment of EMU. Having said that, the decline of the stabilisation provided - and therefore the increased symmetry among the member states - should not be directly linked to the establishment of EMU. While it is probable that EMU had an effect on the asymmetry problem in the direction of Commission's view - stimulating more symmetry and a decline of gains from further centralisation of fiscal policies - it should be kept in mind that there can be other factors that played their role in the increased symmetry in EMU. The model presented in this paper, however, does not distinguish any particular reason for this increased asymmetry, but rather paints the general picture.

Some aspects of an insurance scheme - namely the financing and distribution of the funds created, and the political questions linked to them - have been omitted in the study; however, as stated, the aim was to investigate if the EMU had become more prone to asymmetric shocks in time. To that purpose, the model showed that the general tendency over time has been a decrease of stabilisation provided by centralised insurance schemes. Also the global financial crisis has been left out of the investigation, due to its severity that resulted in high-profile bail-out schemes that were not conceivable before the crisis began, therefore - for the lack of a better term - posing an anomaly in the EMU.

This study served as a general inquiry to the recently questioned ability of EMU to withstand the asymmetric shocks. With sovereign debt crisis and increased spillovers and political foot-dragging, EMU has suffered in the global financial crisis;

\footnotetext{
13 However note that the 1984-2007 coverage of 22\% is still higher than I and V's (1993) estimation of $19 \%$ shock coverage for the 1980-1989 period.
} 
however up till the financial crisis, this paper argues that EMU has become a more symmetric and therefore a stable monetary union, arguing that a creation of an insurance scheme is not profitable in the medium-to-long-run.

However, the overall shock coverage is still higher than the estimates of I and V (1993), and therefore suggests that for the in-between years, EMU would have benefited from such a scheme. In the light of the financial crisis - though not discussed in detail - and the use of fiscal schemes to offset the shock, it can be argued that a similar scheme to the one discussed in this paper - designed for a limited period of time and of limited financial capabilities to not cause further problems in the future - can be of use to EMU, at least in the short run. 


\section{References:}

Babetskii, I. (2004). 'EU Enlargement and Endogeneity of some OCA Criteria: Evidence from the CEECs'. Working Paper Series, 2/2004. Czech National Bank.

Bajo-Rubio, O., and Díaz-Roldán, C. (2000). 'Insurance Mechanisms Against Asymmetric Shocks In A Monetary Union: A Proposal With An Application To EMU'. Working Papers, 00-08, Asociación Española de Economía y Finanzas Internacionales.

Bayoumi, T., and Masson, P.R. (1995). Fiscal Flows in the United States and Canada: Lessons for Monetary Union in Europe. European Economic Review, 39, 253-74.

Bayoumi, T., and Masson, P.R. (1998). Liability-Creating Versus Non-Liability-Creating Fiscal Stabilisation Policies: Ricardian Equivalence, Fiscal Stabilisation, and EMU, The Economic Journal, 108(449), 1026-1045.

BBC (2004). Greece Admits Fudging Euro Entry. Retrieved: May 22, 2011, from: http://news.bbc.co.uk/2/hi/business/4012869.stm

Berger, H., and Nitsch, V. (2008). Zooming Out: The Trade Effect of the Euro in Historical Perspective. Journal of International Money and Finance, 27(8), 1244-1260.

Berger, H., and Nitsch, V. (2010). 'Wearing Corset, Losing Shape: The Euro's Effect on Trade Imbalances'. Working Paper, 10/226, IMF.

Bini Smaghi L. (2007). 'With or without prejudice to price stability?' Speech at the Barclays Capital Annual Conference, London, May 24.

Botero, J. et al. (2004). The Regulation of Labor. Quarterly Journal of Economics, 119, 1339-1380.

Braithwaite, T., et al. (2008). Iceland and UK Clash on Crisis. Retrieved: Feb 9, 2009, from: http://us.ft.com/ftgateway/superpage.ft?news_id=fto100920081802335371

Broz, T. (2008). 'The Introduction of the Euro in Central and Eastern European Countries Is it Economically Justifiable?' Working Papers, 0801, Zagreb: The Institute of Economics.

Buti, M., and van den Noord, P. (2004). Fiscal Policy in EMU: Rules, Discretion and Political Incentives. European Economy - Economic Papers, 206.

Buti, M., and van den Noord, P. (2009). The Euro: The Past Successes and New Challenges. National Institute Economic Review, 208, 68-85.

Catenaro, M. (2000). 'Macroeconomic Policy Interactions in the EMU: A Case For Fiscal Policy Co-Ordination'. Department Of Economics Discussion Papers, 0003, Department Of Economics, University Of Surrey.

Christodoulakis, N. (2009). 'Ten Years Of EMU: Convergence, Divergence And New Policy Priorities'. GreeSe Paper, No 22, Hellenic Observatory Papers On Greece And Southeast Europe. Retrieved: May 27, 2010, from: http://eprints.1se.ac.uk/23192/1/GreeSE_No_22.pdf 
Clar, M., Dreger,C. and Ramos, R. (2007). 'Wage Flexibility and Labour Market Institutions: A Meta Analysis'. IZA Discussion Papers, No 2581, IZA. Retrieved: May 17, 2010, from: http://www.econstor.eu/dspace/bitstream/10419/33997/1/527494925.pdf

Crossley, T., and Low, H. (2004). 'When Might Unemployment Insurance Matter? Credit Constraints And The Cost Of Saving'. Department of Economics Working Paper Series, 2004-04, Mcmaster University.

Cuaresma, C.J., and Amador, F.O. (2007). 'Business Cycle Convergence In Europe: A First Look At The Second Moment'. Research Seminar, Narodowy Bank Polski.

De Grauwe, P. (2005). Economics of Monetary Union. $6^{\text {th }}$ Ed. New York: Oxford University Press.

De Grauwe, P. (2006). What Have We Learnt about Monetary Integration Since the Maastricht Treaty? Journal of Common Market Studies, 44(4), 711-730.

De Grauwe, P., and Moesen, W. (2009). 'Gains for All: A Proposal for a Common Euro Bond'. Intereconomics, May/June, 132-135.

De Grauwe, P., and Senegas, M. (2003). 'Monetary Policy in EMU When the Transmission Is Assymmetric and Uncertain'. CESifo Working Paper Series, No. 891.

Delors Report (1989). 'Report on Economic and Monetary Union in the European Community'. Committee for the Study of Economic and Monetary Union. Luxembourg: Office for Official Publications of the EC.

Delpla, J. and von Weizsäcker, J. (2010). 'The Blue Bond proposal'. Bruegel Policy Brief, 2010/03, Brussels.

Demyanyk, Y., and Volosovych, V. (2005). 'Asymmetry Of Output Shocks In The European Union: The Difference Between Acceding And Current Members'. CEPR Discussion Papers, No 4847, CEPR.

Demyanyk, Y., Ostergaard,C., and Sorensen, B.E., (2008). 'Risk Sharing and Portfolio Allocation in EMU'. European Economy - Economic Papers, No. 334.

Dullien S., and Schwarzer D. (2005). 'The Eurozone Under Serious Pressure. Regional Economic Cycles in the Monetary Union Need to be Stabilised'. Stiftung Weissenschaft and Politik, German Institute for International and Security Affairs, SWP Comments, No. 22, June.

Edwards, S. (2008). 'Sequencing of Reforms, Financial Globalisation, and Macroeconomic Vulnerability'. Working Paper, 14384, NBER Working Paper Series.

European Commission (1990). 'One Market, One Money. European Economy: An Evaluation of the Potential Benefits and Costs of Forming an Economic and Monetary Union'. European Economy, No. 44.

European Commission (2006). Public Finances in EMU - 2006. European Economy, 3. 
European Commission (2009a). Economic Crisis in Europe: Causes, Consequences and Responses. European Economy, 7.

European Commission (2009b). Public Finances in EMU 2009. European Economy, 5.

Eurostat (2004). 'Report by Eurostat on the Revision of the Greek Government Deficit and Debt Figures'. Luxembourg: Eurostat.

Evers, M.P. (2006). Federal Fiscal Transfers in Monetary Unions: A NOEM Approach. International Tax and Public Finance, 13(4), 463-488.

Faiola, A. (2010). Greece's Economic Crisis Could Signal Trouble for Its Neighbors. Retrieved: May 22, 2011, from: http://www.washingtonpost.com/wpdyn/content/story/2010/02/09/ST2010020904032.html?hpid=topnews

Fatas, A. (1998). Does EMU Need A Fiscal Federation? Economic Policy, 13(26), EMU, $165-203$.

Ferreiro, J., Garcia-del-Valle, M.T., and Gomez, C. (2009). Is the Composition of Public Expenditures Converging in EMU Countries?. Journal of Post Keynesian Studies, 31(3), 459-484.

Frankel, J.A, and Rose, A.K. (1997). Is EMU More Justifiable Ex Post Than Ex Ante? European Economic Review, 41, 753-760.

Gros, D., and Mayer, T. (2010). How to deal with sovereign default in Europe: Create the European Monetary Fund now! CEPS Policy Brief, CEPS.

Hall, A. (2008). Pressure Mounts on Brown to Protect All Bank Savings after Germany Promises Iron-cast Guarantee. Retrieved: Feb 9, 2009, from: http://www.dailymail.co.uk/news/article-1069132/Pressure-mounts-Brown-protect-ALLbank-savings-Germany-promises-cast-iron-guarantee.html

Hammond, G.W. and Von Hagen, J. (1998). Regional Insurance Against Asymmetric Shocks: An Empirical Study for the European Community, The Manchester School, 66 (3), 331-353.

HM Treasury (2003). EMU And Labour Market Flexibility. London: HM Treasury. Retrieved: May 7, 2009, from: http://news.bbc.co.uk/2/shared/spl/hi/europe/03/euro/pdf/8.pdf.

Imre, Ö. (2010). The Effect of Fiscal Federalism to Absorb Asymmetric Shocks in Economic and Monetary Union. Master Thesis. Istanbul: Marmara University.

Italianer, A., and Vanheukelen, M. (1993). 'Proposals for Community Stabilization Mechanisms: Some Historical Applications'. The Economics of Community Public Finance, European Economy, Reports And Studies No 5.

Jones, E. (2009). 'European Fiscal Policy Co-ordination and the Persistent Myth of Stabilization'. Leia S. Talani (ed.), The Future of the EMU. Great Britain: Palgrave Macmillan. 
Kenen, P. (1969). 'The Theory of Optimum Currency Areas: An Eclectic View'. Robert E. Mundell and Alexander K. Swoboda (eds.), Monetary Problems in the International Economy. Chicago: University Of Chicago Press.

Knotek II., E.S., (2007). How Useful is Okun's Law? Economic Review, Federal Reserve Bank of Kansas City, 3, 5-33.

Krugman, P. (1993). 'Lessons Of Massachusetts For EMU'. Francisco Torres and Francesco Giavazzi (eds.), Adjustment And Growth In The European Monetary Union. Cambridge: Cambridge University Press.

Lane, P. R. (2008). EMU and Financial Integration. IIIS Discussion Papers, No. 272, IIIS.

Lian, X. (2008). EU split on how to tackle financial crisis. Retrieved: Feb 12, 2009, from: http://www.chinadaily.com.cn/world/2008 10/07/ content_7082634.htm

Lockwood, B. (2002). Distributive Politics and the Costs of Centralization. Review of Economic Studies, 69(2), 313-37.

McKinnon, R. (1963). Optimum Currency Area, The American Economic Review 53(4), 717 725.

McNamara, K.R. (2005). 'Economic and Monetary Union: Innovation and Challenges for the Euro'. Helen Wallace, William Wallace, and Mark A. Pollack (eds.), Policy Making in the European Union. Oxford: Oxford University Press.

Mongelli, F. P. (2002). "New" Views on the Optimum Currency Area Theory: What is EMU Telling US?' Working Paper Series, No. 138, ECB.

Mundell, R.A. (1961). A Theory of Optimum Currency Areas. The American Economic Review, 51(4), 657-665.

Musgrave, R.A. (2008). Public Finance and Three Branch Model. Journal of Economics and Finance, 32, 334-339.

Oates, W.E. (1968). The Theory of Public Finance in a Federal System. The Canadian Journal of Economics, 1(1), 37-54.

Oates, W.E. (1972). Fiscal Federalism. New York: Harcourt Brace Jovanovich

Oates, W.E. (1999). An Essay On Fiscal Federalism. Journal Of Economic Literature, 37(3), 1120-1149.

Oates, W.E. (2006). 'On the Theory and Practice of Fiscal Decentralisation'. IFIR Working Paper, No 2006-05, IFIR.

OECD (2009). Investment News. Issue 10, June.

Rosen, H. (2005). Public Finance. $7^{\text {th }}$ ed. McGraw-Hill

Sala-I-Martin, X., and Sachs, J. (1991). 'Fiscal Federalism and Optimum Currency Areas: Evidence for Europe from the United States', NBER Working Paper Series, No 3855 , NBER. 
Schiavo, S. (2008). 'Financial Integration, GDP Correlation and the Endogeneity of Optimum Currency Areas'. Working Papers, No.25, Università di Verona, Dipartimento di Scienze Economiche.

Siedschlag, I. (2008). 'Macroeconomic Differentials and Adjustment in the Euro Area'. SUERF Studies, No:2008/3, SUERF - The European Money and Finance Forum.

Von Hagen, J. (1992). 'Fiscal Arrangements in a Monetary Union - Some Evidence from the US'. Donald E. Fair and Christian de Boissieux (eds.), Fiscal Policy, Taxes, and the Financial System in an Increasingly Integrated Europe, Dordrecht: Kluwer Academic Publishers.

Von Hagen, J. (1998). 'Fiscal Policy and Intra-national Risk-Sharing'. ZEI Discussion Papers, No B 98-13, ZEI.

Weingast, B.R. (1995). The Economic Role Of Political Institutions: Market-Preserving Federalism And Economic Development. Journal of Law Economics and Organization, $11,1-31$.

Weingast, B.R. (2007). Second Generation Fiscal Federalism: Implications For Decentralized Democratic Governance And Economic Development. In: Conference On New Perspectives On Fiscal Federalism: Intergovernmental Relations, Competition And Accountability.

Werner Report (1970). 'Report to the Council and the Commission on the Realization by Stages of Economic and Monetary Union in the Community'. Council and Commission of the EC, Bulletin of the EC, Supplement 11.

Wildasin, D.E. (2000). Factor Mobility and Fiscal Policy In The EU: Policy Issues And Analytical Approaches, Economic Policy, 15(31), 339-378. 